IA WAE NGE IIVIAGICAE WATIONAL LAEOARTOFY

\title{
Test Stand for Linear Induction Accelerator Optimization
}

M. Ong, B. DeHope, K. Griffen, D. Goerz, R. Kihara, G. Vogtlin, J. M. Zentler, R. Scarpetti

June 3, 2003

2003 Pulsed Power Conference, Dallas, TX, June 16-19, 2003 
This document was prepared as an account of work sponsored by an agency of the United States Government. Neither the United States Government nor the University of California nor any of their employees, makes any warranty, express or implied, or assumes any legal liability or responsibility for the accuracy, completeness, or usefulness of any information, apparatus, product, or process disclosed, or represents that its use would not infringe privately owned rights. Reference herein to any specific commercial product, process, or service by trade name, trademark, manufacturer, or otherwise, does not necessarily constitute or imply its endorsement, recommendation, or favoring by the United States Government or the University of California. The views and opinions of authors expressed herein do not necessarily state or reflect those of the United States Government or the University of California, and shall not be used for advertising or product endorsement purposes. 


\title{
TEST STAND FOR LINEAR INDUCTION ACCELERATOR OPTIMIZATION *
}

\author{
Mike Ong, Bill DeHope, Ken Griffin, Dave Goerz, Ron Kihara, George Vogtlin and \\ Jan Mark Zentler \\ Lawrence Livermore National Laboratory, PO Box 808, L-153 \\ Livermore, CA, 94550
}

Ray Scarpetti

Los Alamos National Laboratory, P.O. Box 1663

Los Alamos, NM 87545

\begin{abstract}
Lawrence Livermore National Laboratory has designed and constructed a test stand to improve the voltage regulation in our Flash X-Ray (FXR) accelerator cell. The goal is to create a more mono-energetic electron beam that will create an $x$-ray source with a smaller spot size. Studying the interaction of the beam and pulsepower system with the accelerator cell will improve the design of high-current accelerators at Livermore and elsewhere.

On the test stand, a standard FXR cell is driven by a flexible pulse-power system and the beam current is simulated with a switched center conductor. The test stand is fully instrumented with high-speed digitizers to document the effect of impedance mismatches when the cell is operated under various full-voltage conditions. A time-domain reflectometry technique was also developed to characterize the beam and cell interactions by measuring the impedance of the accelerator and pulsepower component.

Computer models are being developed in parallel with the testing program to validate the measurements and evaluate different design changes. Both $3 \mathrm{D}$ transient electromagnetic and circuit models are being used.
\end{abstract}

\section{FXR Performance and Limitations}

The LLNL FXR is an induction linear accelerator that produces pulsed $x$-rays and is used regularly and reliably on explosive experiments since it completion in 1982. In recent years FXR has been incrementally improved, adding double-pulse capability, increasing dose, and reducing $x$-ray spot-size [1].

The accelerator generates a $3 \mathrm{kA}$ electron beam with 17 $\mathrm{MeV}$ of energy. Our present pulse length is about $70 \mathrm{~ns}$, the dose at $1 \mathrm{~m}$ is over $400 \mathrm{Rad}$, and the spot-size is in the lower $2 \mathrm{~mm}$ range (full-width half-maximum).
Based on results regarding dose and $x$-ray spot-size from DARHT [2] and other accelerator, we believe that we could further improve the performance of FXR. In 2001 during the construction of a very large explosive containment facility, the accelerator was not needed for physics experiments. We had the opportunity to study the limitations of FXR along with colleagues from the LLNL Beam Research Program.

A large number of measurements were completed that included, time-resolved electron and x-ray beam-size, beam emittance at the injector and at the end of the accelerator, cell voltage, target-beam interactions, and effect of different injector settings. To understand electron energy variations, cell voltage measurements were compared against time-resolved electron energy measurements made the previous year. The energy measurement was made possible by the loan of equipment and personnel from the DARHT Project at Los Alamos National Lab.

Incorporating the results from the measurement campaign, computer modeling of the electronic beam at the final focus magnet identified two areas of improvement that might significantly impact $x$-ray spotsize: beam energy variations and beam emittance. From our diagnostic experience, we also understood that the performance of FXR as a system of many components needed optimizing. For example, timing jitter between accelerator cells was too high. A third area for improvement was added: FXR as a system.

There were two sources of beam energy variations: the pulse-power voltage variations and the beam-induced voltages. The first two terms of the equation (1) includes the voltage that is generated by the Marx and Blumlein, along with their interactions with the time-isolation and power feed coaxial lines and cell features. The injector voltage has added complexity because of the reflections in the cathode and anode stalks. The third term is defined as the beam-induced voltage that gets reflected back from the different cell components into the acceleration gap. This is related to beam loading, but the impedance

\footnotetext{
* This work was performed under the auspices of the U.S. Department of Energy by the University of California. Lawrence Livermore National Laboratory under Contract No. 7405-Eng-48.
} 
mismatches in the cell and pulse-power system creates a much more dynamic process than the name "loading" implies.

$$
E_{V \text { injector }}+E_{V \text { accelerator }}-E_{V \text { beam-induced }}=E_{\text {target }}
$$

The beam emittance appears to be high out of the injector and the accelerator contribution seems to be small. An effort is underway to design a new lower emittance cathode head.

It is difficult to further diagnose the FXR accelerator because of the busy experimental shot schedule. A limited number of measurements have been completed to characterize the performance of the FXR system. Components that need adjustment or replacement have been identified. These activities are being accomplished during the FXR down-time on the production schedule.

We are working on alternate designs to produce a more mono-energetic beam. Because of the limitation of the computers and codes, the voltage variation problems were not fully modeled when the accelerator was designed more than 20 years ago. Now, we have better modeling capabilities, diagnostic equipment, and design experience gained from the development of other accelerators. Both the pulse-power system and accelerator cell can be improved. Our approach is to generate a well-regulated voltage pulse of sufficient length and transport it to the cell while minimizing early reflections. This should also mitigate reflections associated with the beam-induced pulse.

Given the high demands for our production radiography machine, it was decided that alternative designs could not be evaluated on FXR. Instead, we constructed a Singlecell Test Stand that would allow new designs to be studied without interfering with the shot schedule or jeopardizing FXR reliability.

\section{Test Stand}

A drawing of the Single-cell Test Stand is shown in Figure 1. The pulse-power system consists of a Marx generator (shown on left) and a Blumlein under the cell. Time isolation lines are in the upper arms of the "Y" structure. The attached to the cell is a beam load simulator. The passive design has been tested. An active load which can be switched on at any time is being designed. The pulse-power load resistors are located at the top and bottom of the cell.

Wherever possible, spare FXR parts were used in the construction of the Test Stand. The cell is an unused unit. The Marx generator normally feeds four Blumleins/cells, and the one for the Test Stand was modified to fire into only one cell. The Stand was constructed in the high-bay of the FXR accelerator so that the auxiliary systems (such air condition, water cooling, high-dielectric oil, deionized water, electrical power, and vacuum) could be provided by existing FXR equipment.

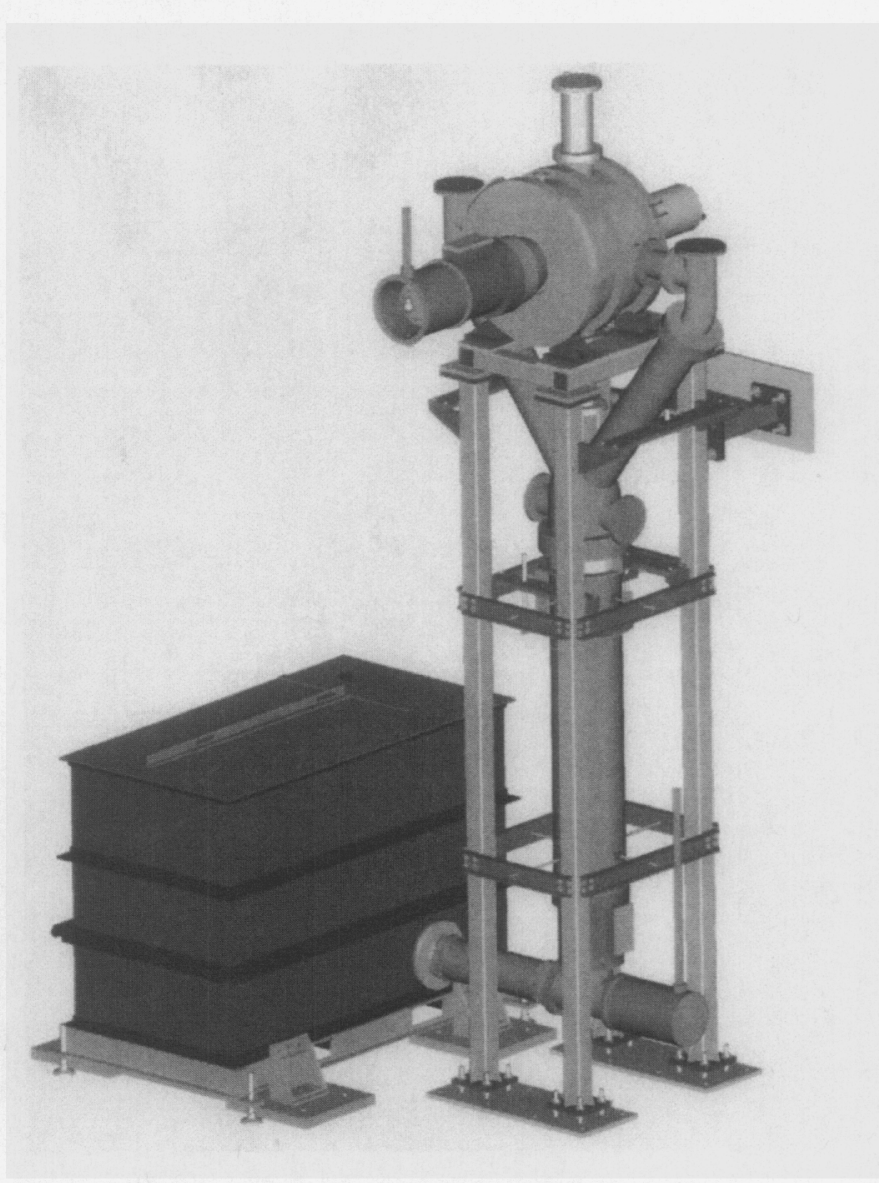

Figure 1. A drawing of the FXR Single-cell Test Stand shows the pulse-power system, cell, and beam-simulator that being used to evaluate new designs with improved voltage regulation.

The Test Stand pulse-power system incorporated changes in the Marx that increases reliability of erection. The power supplies was also upgraded so the Marx could be quickly charged and fired to support longevity testing of new components. Not shown are the trigger systems for the Marx and Blumlein. These were designed to produce very low jitter to study the effect of timing changes between the Marx and Blumleim.

The Test Stand includes a large number of sensors to measure the effect of various component changes. (See Figure 2.) The voltages into and out of the Marx generator and the voltage out of the Blumlein are recorded. D-dot sensors are installed along the two time isolation lines. These allow us to determine the direction of travel of the reflected pulses, and estimate the locations of the impedance mismatches. A capacitive sensor monitors the cell voltage near the feed, while the voltage at the cell load-resistor is measured by a geometric voltage divider built into the resistor. The output of the cell at the gap is monitored by D-dot sensors, and the electric field uniformity can be checked. The state of the ferrite is estimated from B-dots sensors that measure current. 


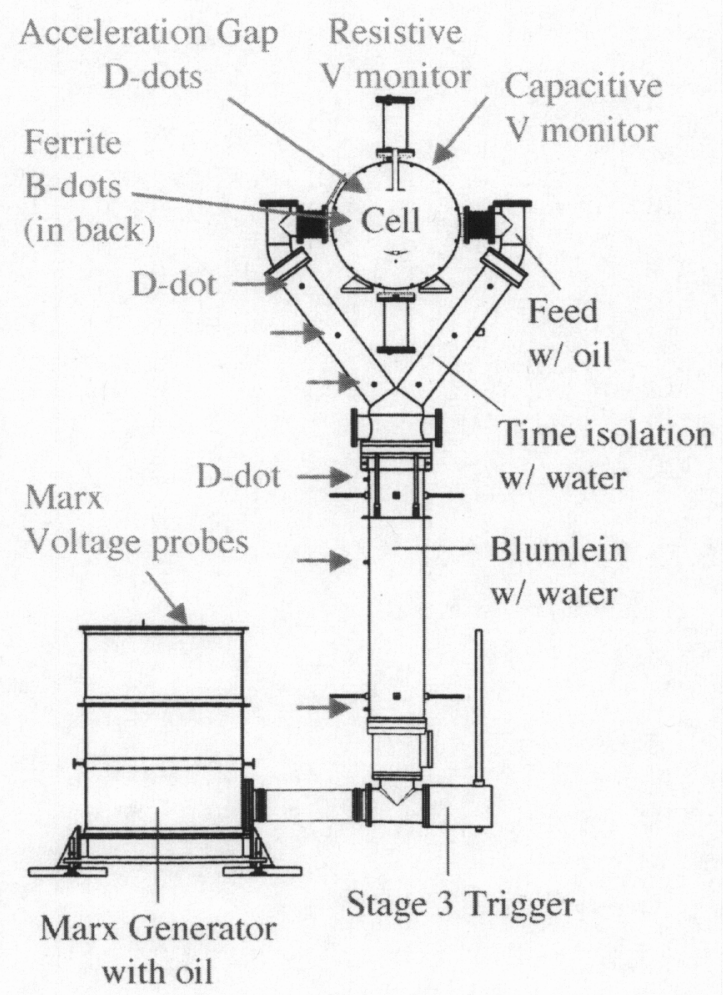

Figure 2. The Test Stand includes a large number of sensors to measure the effect of component changes.

Signals from the sensors are recorded on high-speed digitizers. Twelve channels are sampled at $5 \mathrm{GS} / \mathrm{s}$, and 4 channels at $20 \mathrm{GS} / \mathrm{s}$. The record length is greater than 2 $\mu$ so that we can view the whole process of charging, firing, and ring-down anywhere on the Test Stand. The different digitizers are synchronized so that absolute time and timing jitter can be accurately determined.

The data collection process has been automated. Computers retrieve the waveforms from the digitizers and a server supports data sharing by the experimentalists and analysts.

The Test Stand has been in operation for about 6 months. The data we have analyzed is invaluable for improving the performance of FXR.

\section{Test Stand Studies}

The goal of the Test Stand studies is to generate a voltage pulse at the acceleration gap that varies by no more than $1 \%$ for a duration that encompasses most of the beam, about $60 \mathrm{~ns}$. This includes the contribution for the beam-induced voltage.

The studies are listed in Table 1. They are categorized by the major accelerator components starting at the Marx generator and ending at the beam. By each component, the effect on the gap voltage is described along with possible improvements. The desire is to improve each of these components so in total they create less than a $1 \%$ voltage variation.

Table 1. Test Stand Studies.

\begin{tabular}{|c|c|c|}
\hline Components & $\begin{array}{c}\text { Effect on Gap } \\
\text { Voltage }\end{array}$ & $\begin{array}{c}\text { Possible } \\
\text { Improvements }\end{array}$ \\
\hline $\begin{array}{l}\text { Marx charge } \\
\text { voltage }\end{array}$ & $\begin{array}{l}\text { absolute voltage } \\
\text { changes }\end{array}$ & $\begin{array}{l}\text { high-precision } \\
\text { power supplies }\end{array}$ \\
\hline Blumlein & $\begin{array}{c}\text { lower voltage at } \\
\text { end of pulse }\end{array}$ & $\begin{array}{l}\text { equalize inner and } \\
\text { outer line lengths }\end{array}$ \\
\hline $\begin{array}{l}\text { Time } \\
\text { isolation lines }\end{array}$ & $\begin{array}{c}\text { voltage } \\
\text { variations at end } \\
\text { of pulse }\end{array}$ & $\begin{array}{l}\text { reduce impedance } \\
\text { mismatches, } \\
\text { longer line }\end{array}$ \\
\hline Cell & $\begin{array}{c}\text { reflections from } \\
\text { both PP system } \\
\text { and induced } \\
\text { voltage }\end{array}$ & $\begin{array}{c}\text { reduce impedance } \\
\text { mismatch in cell, } \\
\text { at feed, and load } \\
\text { resistors }\end{array}$ \\
\hline $\begin{array}{l}\text { Cell load } \\
\text { resistors }\end{array}$ & $\begin{array}{l}\text { absolute } \\
\text { resistance } \\
\text { change }\end{array}$ & $\begin{array}{l}\text { better temperature } \\
\text { control }\end{array}$ \\
\hline Cell ferrite & $\begin{array}{l}\text { reduce pulse } \\
\text { duration }\end{array}$ & active ferrite reset \\
\hline Timing & $\begin{array}{l}\text { absolute } \\
\text { voltage, droop } \\
\text { and rise }\end{array}$ & $\begin{array}{l}\text { reduce timing jitter } \\
\text { between erection } \\
\text { and firing cell }\end{array}$ \\
\hline $\begin{array}{l}\text { Electron } \\
\text { beam }\end{array}$ & $\begin{array}{c}\text { voltage } \\
\text { oscillates at } \\
\text { beginning of } \\
\text { pulse }\end{array}$ & $\begin{array}{c}\text { reduce impedance } \\
\text { mismatch in cell, } \\
\text { at feed, and load } \\
\text { resistors }\end{array}$ \\
\hline
\end{tabular}

From our measurement campaign on the Test Stand and analysis, the cause of the voltage fluctuations in the accelerator gap is well understood. The picture is complicated because the different components affect the pulse flatness at different times. Some upgrades can correct problems created by multiple sources. For example, improving the impedance match between components reduces reflections that start with the Blumlein pulse and the beam-induced pulse.

Some changes on the Stand Test and FXR are easy to implement, such as adding precision high-voltage charging power supplies for the Marx. Others are more difficult, e.g., reducing impedance mismatches between the components. Circuit models created by analysis of the mechanical features and refined by measurements on the Test Stand identify areas requiring redesign. New designs will be modeled with $3 \mathrm{D}$ transient codes. They will also be thoroughly evaluated on the Test Stand before FXR is modified.

The beam-induced voltage oscillates at the beginning of the pulse. It was characterized on FXR with the cell powered and unpowered. Since the Test Stand does not include a beam, we are studying the problem using two different techniques. The first utilizes low-power Timedomain Reflectometry (TDR) and other involves generating high-currents on a center conductor simulating the beam. The conductor is grounded on one end, and can 
be terminated by a high-voltage resistor on the other end. The resistor is connected to the conductor through a gas switch. This will allow us to change the timing between the cell voltage and beam "loading".

The TDR measurement configuration is shown in Figure 3. A $50 \Omega$ air-line is attached to the cell with the center conductor passing through the middle of the cell. The TDR measurements allow us to quantify the impedance of each internal component and exactly locate in time and position the mismatches. We can open the covers at different locations along the transmission lines and short out sections, since this is a low-power diagnostic. Each shorted area can then be temporarily correlated to features on the waveform.

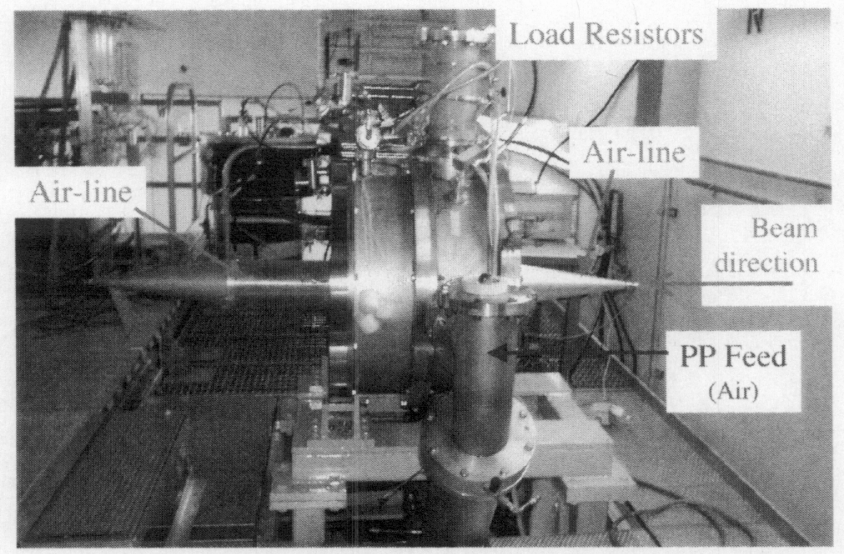

Figure 3. The air-line shown attached to the cell is used to measure the impedance changes with time experience by the electron beam.

While work is proceeding on the Test Stand, highbandwidth measurements have been completed on FXR to determine machine performance. Analysis of the data points to unique problems that cannot be answered on the Test Stand. An example is the effect of the composite voltage changes from the ten cells on the injector diode. The FXR beam and cell diagnostic system is being upgraded with more channels and higher bandwidth digitizers. This upgrade will improve both the reliability and performance of FXR.

We want to acknowledge the contributions of Blake Kreitzer, Don Fleming, Jim Bowman, and other mechanical and electronic personnel who worked hard to build the Test Stand. We especially want to thank Brian Guidry for his insights crafted from his high-bandwidth FXR measurements and analysis.

\section{SUMMARY}

LLNL has built a Single-cell Test Stand to evaluate design options for improving FXR voltage regulation of the pulse-power system and in the acceleration cell. A large number of enhancements are being studied including better control of the Marx voltage, flatter Blumlein pulse, impedance matching of the components including the cell, longer ferrite operation, and reduced timing jitter. In order to produce a smaller x-ray beam and maintain reliability, other components on FXR must also be upgraded or tuned-up, such as a low-emittance cathode and timing of the different accelerator cells.

\section{REFERENCES}

[1] Multhauf, L.G., "The LLNL Flash X-ray Induction Linear Accelerator", LLNL, Livermore, CA, UCRL-JC148543, Sept 19, 2002.

[2] Burns, M.J., et.al, "DARHT Accelerators Update and Plans for Initial Operation", Particle Accelerator Conference, NY, 617-621, 1999. 